\title{
EFFECTS OF OPERATING VARIABLES ON DURABILITY OF FUEL BRIQUETTES FROM RICE HUSKS AND CORN COBS
}

\section{Authors: Rukayya I. Muazu and Julia A. Stegemann}

Institution for authors

Centre for Resource Efficiency \& the Environment, Department of Civil, Environmental \& Geomatic Engineering, University College London, United Kingdom

email: rukayya.ibrahim.11@ucl.ac.uk

email: j.stegemann@ucl.ac.uk

Corresponding author:

Ibrahim Rukayya

Department of Civil, Environmental and Geomatic Engineering, University College London

Chadwick building, Gower Street, London, WC1E 6BT

mobile: $+44(0) 7531697254$

\section{ABSTRACT}

Biomass densification processes increase fuel energy density for more efficient transport. This study presents new data to show that blending different types of biomass improves the properties of densified biomass briquettes. The specific objectives were to investigate the effects of sample batch (biomass source), material ratio (rice husks to corn cobs), addition of binder (starch and water mixture) and compaction pressure, on briquette properties, using a factorial experiment.

Briquettes had a unit density of up to 1.9 times the loose biomass bulk density, and were stronger than briquettes from the individual materials. Considering average values from two biomass sources, an unconfined compressive strength of $176 \mathrm{kPa}$ was achieved at a compaction pressure of $31 \mathrm{MPa}$ for a 3:7 blend of rice husks to corn cobs with $10 \%$ binder. These briquettes were durable, with only $4 \%$ mass loss during abrasion and $10 \%$ mass loss during shattering tests. They absorbed $36 \%$ less water than loose corn cobs. Statistical analysis of the results showed that starch and water addition was required for adequate briquette strength, but significantly reduced green and relaxed densities. The source of the biomass had a significant effect on densification, which emphasises the need to understand factors underlying biomass variability.

Key words: fuel; briquettes; blends; rice husks; corn cobs; density; durability 


\section{INTRODUCTION}

\subsection{Energy from agricultural biomass}

Biomass has received tremendous attention both in developed and developing countries as a renewable energy source [eg. 1,2]. A major drawback of biomass energy is the competition between energy and food crops for cultivable land [3,4]. This issue is resolved by use of agricultural residues, which would otherwise be wasted, for energy generation. However, although agricultural residues form one of the biggest potential sources of biomass energy in most developing countries, their efficient exploitation for energy is presently uncommon $[1,5]$. At present, agricultural residues are combusted directly without optimisation of energy efficiency or control of air emissions, or they are left on farm land/processing sites to decay, potentially releasing greenhouse gases and/or polluting surface waters.

\subsection{Biomass densification}

Since direct use of unprocessed biomass feedstock can lead to problems during storage, transportation, handling and processing [6], numerous strategies have been developed to convert various types of biomass into secondary fuels that have better characteristics compared to the parent material(s). These strategies include biomass densification.

Biomass densification involves its compaction into a pellet or briquette of up to ten times higher density than the parent material(s) $[7,8]$. Such processing increases biomass bulk and energy density per unit volume, leading to lower storage requirements, more efficient transportation, reduced particulate emissions per unit volume of material transported or combusted, and uniform feeding into industrial equipment such as boilers, gasifiers and domestic stoves for rural applications $[1,9,10]$.

Research by other workers has demonstrated that agricultural residues such as rice husks, corn cobs, olive husks etc. can be densified into briquettes [e.g.,1,10,11]. Due to variations in properties of different biomass materials, some feedstocks are more easily densified than others. Biomass materials with a higher lignin, starch or protein content exhibit better compaction than those with higher cellulosic content [8]. This has prompted addition of biomass containing higher amounts of these components to other biomass. For example, blending sawdust from Scots pine with wheat straw resulted in more durable pellets compared to wheat straw alone [12], rice bran was used as a binder in briquetting rice straw [13] and olive refuse blended with fibrous paper mill waste [55], for reportedly improved briquette durability. 


\subsection{Rice husks and corn cobs}

Rice and corn are examples of major crops that result in generation of huge amounts of waste from their cultivation and processing, including rice husks and corn cobs. Around $134 \mathrm{Mt}$ of rice husks were produced globally from $671 \mathrm{Mt}$ of rice production in the year 2008 [14]; in the same year, approximately $135 \mathrm{Mt}$ of corn cobs were produced from $797 \mathrm{Mt}$ of corn production [15].

Table 1 compares energy, ash, moisture contents, bulk density and porosity of rice husks and corn cobs, as gathered from sources in the literature [1,14,16,17,18,19,20-29]. It can be estimated that the total annual generation of rice husks and corn cobs has an energy content of $4 \mathrm{EJ}$, which represents about $1 \%$ of the world total primary energy consumption [30].

Problems have been encountered with the use of briquettes produced from these individual materials. Briquettes produced from rice husks have been reported to cause clogging of industrial boilers and domestic stoves due to their high ash content [31], which is also abrasive and wears equipment quickly due to the high silica content of the rice husk ash [14]. Briquettes produced from corn cobs have a tendency for water absorption due to the high porosity of corn cob particles. High moisture contents are undesirable in thermochemical processes such as pyrolysis and gasification due to the energy requirement for drying of biomass and the reduced heating value of the product gas $[32,33]$.

\subsubsection{Material ratio}

Blending of rice husks and corn cobs will result in fuel briquettes with a lower ash content compared to briquettes produced from rice husks alone. On the other hand, briquettes containing rice husks are expected to absorb less water than briquettes from corn cobs alone, due to the lower water absorbency of the thick outer walls of rice husks [20]. Material ratio is the proportion of individual rice husks or corn cobs residue in the blend of both residues.

\subsubsection{Sample batch}

The variability of biomass materials have resulted in inconsistency in the characteristics of fuel briquettes produced from different types of residues [8,57], this may even apply to the same type of residues grown at different season or different locations. It becomes necessary to understand the influence of the variability on biomass densification and fuel briquette's quality. 


\subsubsection{Binder}

Despite the additional cost, additional binders are often added in densification of biomass residues, as they may not naturally contain adequate proportions of binders.

Starch has been used as a binder in some densification processes, such as in compaction of sorghum residue, and corn cobs individually [34,35], and has been reported to improve briquette characteristics. Starch is a polysaccharide, which is widely available. It has a high energy content and is a good binding agent due to its chemical and structural properties [36]. Addition of water and heat to starch granules causes swelling, which results in the formation of intermolecular hydrogen bonds between the amylose and amylopectin components of starch, followed by loss of the individual crystalline structure of the two components [37]. This leads to formation of a viscous solution that undergoes retrogradation, i.e., gelling, during cooling or storage. The viscosity of hydrated starch increases its shear and tensile strengths. The fluidity and viscoelasticity of the produced solution [37] gives it the ability to occupy the void spaces present within and between biomass particles, forming solid bridges that become stronger upon air-drying.

\subsubsection{Pressure}

During the densification process, an increase in pressure results in plastic and elastic deformation, molecule diffusion and closing up of void spaces between particles to form a compacted solid. Briquettes manufactured at lower pressures of 30 to $60 \mathrm{MPa}$ crumble easily, while those produced at higher pressures of 150 to $250 \mathrm{MPa}$ remain compacted and durable [57], for example, increasing the compaction pressure from 1 to $10 \mathrm{MPa}$ increased the shear strength of briquettes from $2.8 \times 10^{-2} \mathrm{kPa}$ to $9.6 \times 10^{-2} \mathrm{kPa}$ [43]. Currently, efforts are directed towards improving the quality of fuel briquettes produced at lower pressures.

\subsubsection{Objectives}

This study investigated the effects of sample batch (biomass source), material ratio, addition of binder, and compaction pressure, on properties related to the durability of fuel briquettes made from blends of rice husks and corn cobs, including their strength, resistance to impact and abrasion, and water absorption. 


\section{MATERIALS AND METHODS}

\subsection{Sourcing, preparation and characterisation of raw materials}

Two bulk samples of air dried rice husks, and corn cobs, as well as a sample of starch were sourced and collected from local farms and milling sites in Niger state, Nigeria. Rice husks were used as received from the milling site, since they have a particle size of $<2 \mathrm{~mm}$, which can readily undergo densification. The mass median diameter ("D50") of the rice husks was $0.7 \mathrm{~mm}$. Corn cobs were used with a particle size of $<1.6 \mathrm{~mm}$, based on preliminary experiments which found that larger particles $(2-10 \mathrm{~mm})$ were less easily compacted. Corn cob particles obtained using a hammer mill fitted with $1 \mathrm{~mm}$ screen were blended with larger particles $(1-1.6 \mathrm{~mm})$ that had been manually crushed. The mass median diameter of the resulting blend was $0.8 \mathrm{~mm}$. Characterisation of rice husks and corn cobs included determination of bulk density by BS EN 15103 [38], moisture content by BS EN 14774-2 [39], particle size by sieve analysis according to DD CENT/TS 15149-2 [40], water absorption by adaptation of BS EN 772-21 [41] and specific gravity using a Micromeritics helium pycnometer (ACCU Pyc 1330). The porosity of materials was determined using equation 1.

$$
\text { Porosity }=\left(1-\frac{\rho}{S G}\right) X 100
$$

where

$\rho=$ density of material $\left(\mathrm{kg} / \mathrm{m}^{3}\right.$ dry basis $)$

$S G=$ specific gravity of material $\left(\mathrm{kg} / \mathrm{m}^{3}\right)$

The particle morphology of three replicates of each sample of rice husks and milled corn cobs was examined using a Jeol JSM-6480LV high-performance, variable pressure analytical scanning electron microscope (SEM). Energy-dispersive x-ray spectroscopy (Oxford Instrument INCAx-sight EDS-system) was used for microanalysis of the solid phases viewed by SEM.

Pure unrefined cassava starch was prepared as a binder by mixing into a paste with water at a mass ratio of $2: 3$, for 5 minutes prior to its addition to the rice husk and corn cob blends. The binder contents for the experiments reported here were chosen based on preliminary experiments with 5 to $35 \%$ starch mixture. 


\subsection{Experimental design and analysis}

A factorial experimental design method involving 24 runs was employed for production of briquettes. The variables investigated in this study were chosen based on their expected influence on briquette quality: sample batch (S), i.e, two different samples, A and B, of rice husks and corn cobs obtained for two different seasons and farms sites, material ratio (M), i.e., percentage mass of rice husks in the blend of rice husks and corn cobs, and binder addition (B), i.e. mass of starch and water added as a percentage of the rice husk and corn cob blend, and compaction pressure $(\mathrm{P})$. The response variables measured were green (immediately after extrusion from the mold) and relaxed (after 24 hours curing) unit density, unconfined compressive strength, mass lost in abrasion and shattering tests (i.e., "durability rating") [59], and water absorption. The methods used to measure these response variables are summarised in Table 2. Unless otherwise specified, each test was repeated for three briquettes.

Two levels (low and high) were selected for each of the independent variables; the $2^{4}$ factorial design that was used for briquette production is shown in columns 2 to 5 of Table 4 , which also shows the measured responses.

Since the effect of water in the binder was confounded with that of the starch in this experiment, additional experimental runs were conducted to assess the effect of water on the response variables, with and without starch. The responses for briquettes containing water only (without starch) are presented in rows $21^{* *}$ to $24 * *$ of Table 4 , for comparison with the results for otherwise similar briquettes produced with both water and starch mixture in rows 9 to 12 . In the statistical analysis, the effect of dry starch on briquette responses was assumed to be the same as when only rice husks and corn cobs residues were used (i.e., with no water or starch in rows $17 * *$ to $20^{* *}$ of Table 4 ).

Statistical effects of variables and their interactions on the responses were calculated based on the individual replicate results shown in columns 7, 9 and 11 of Table 4 [42]. Effects of the variables and interactions between the variables on a response are estimated as the differences between the averages for the high and low levels of a variable or interaction, and the total mean response. The highest order interactions of variables were assumed to be largely due to random noise [42]. Normal probability plots of the effects can be used to visualize the significance of the effects of individual variables on the responses [42]. The estimated effects can be read from the abscissa, against the standard deviation of the normal 
distribution on the ordinate. The scale of the ordinate has been adjusted such that a normal distribution appears as a straight line, i.e., points that lie on the straight line may be a result of normal random variability, whereas those that deviate from the straight line indicate significant effects of these variables or interactions on the response. Analysis of variance was also used to determine the statistical significance of the observed effects [42].

The fitted model for the predicted responses is shown as Equation 2 [42], and Equation 3 was used to calculate the residuals $(\varepsilon)$ of the responses.

$$
\begin{array}{r}
\dot{\mathrm{Y}}=\overline{\mathrm{Y}}+\left(\frac{j 1}{2}\right) * x 1+\left(\frac{j 2}{2}\right) * x 2+\cdots\left(\frac{j n}{2}\right) * X n \\
\mathcal{E}=\mathrm{y}-\dot{\mathrm{Y}} \ldots \ldots \ldots \ldots \ldots \ldots \ldots \ldots \ldots \ldots \ldots \ldots \ldots
\end{array}
$$

Where;

$\bar{\Upsilon}$ is thegrand mean for each set of response data(eg.green density)

$j 1, j 2 \ldots . . . j n$ is the observed main or interaction effect of the variables

$x 1, x 2 \ldots x n$ is the respective sign of the observed effects for each response value

A normal probability plot of the residuals was used to visualize the normality and check that all effects other than those included in the model are explained by random noise.

\subsection{Briquette production}

Biomass and binder blends were weighed out in the proportions indicated in columns 3, 4 and 5 of Table 4 and densified using a simple hand-held laboratory steel mold with an inner diameter of $32 \mathrm{~mm}$, an outer diameter of $51 \mathrm{~mm}$, and length of $100 \mathrm{~mm}$ (Figure 1).

A hydraulic compression testing machine (Controls-04600/FR) was used to compress the blended biomass in the mold to the desired load (column 6 of Table 4), at a rate of $200 \mathrm{~N} / \mathrm{s}$ as shown in Figure 2. Based on previous findings by the author and other researchers $[43,44]$ that a hold time under compression in the mold in excess of 40 seconds has little effect on briquette characteristics, the compacted briquettes were held at the desired compaction pressure of 19 and $31 \mathrm{MPa}$, for 60 seconds, and then extruded from the mold through the hole shown on the right side of the mold base plate in Figure 1. 


\subsection{Briquette curing}

All briquettes produced in the factorial design experiment were cured for 24 hours at $23 \pm$ $2^{\circ} \mathrm{C}$ and relative humidity of $50 \pm 5 \%$ before testing.

New batches of the briquette formulations with the highest relaxed density and those with the highest unconfined compressive strength were made for further testing after curing as follows:

- 24 hours +6 days at $23 \pm 2^{\circ} \mathrm{C}$

- 24 hours at $35^{\circ} \mathrm{C}+6$ days at $23 \pm 2^{\circ} \mathrm{C}$.

The briquettes were cured at $35^{\circ} \mathrm{C}$ to assess the effect of warm weather conditions, e.g., in the source country of the raw materials, Nigeria.

Figure 3 shows some of the briquettes produced.

\section{RESULTS AND DISCUSSION}

\subsection{Properties of loose rice husks and corn cobs}

Table 3 shows the properties of the rice husks and corn cobs measured in this study.

The ash content of the rice husks in Table 3 appears to be consistent with the literature value in Table 1, while that of the corn cobs, though almost twice the literature value, is much lower than that of the rice husks. The moisture contents determined for both the rice husks and corn cobs in this study were similar, although moisture content of corn cobs is commonly found to be higher than that of rice husks, and both our measurements are slightly lower than the ranges reported by others [1,17] (Table 1). This may be due to handling and storage conditions of the materials before the moisture content test, whereby our materials were not fresh, and air drying and hammer milling of the corn cobs is associated with significant moisture loss [17].

Furthermore, the measured solids specific gravities were consistent between samples of each material, but those of the rice husk solids were slightly higher than those of the corn cob solids. This observation may be attributable to the higher ash content of the rice husks, or other differences in composition between rice husks and corn cobs as shown in Table 1 and Table 3. The loose bulk densities of both the rice husks and corn cobs in this study fall within the ranges determined by other workers (Table 1), except for corn cob Sample A which is 
about $40 \%$ higher than expected. The porosities of the rice husks and corn cobs were similar, but also higher than results by others reported in Table 1, with a notable difference between the porosities measured for the two samples of corn cobs, reflecting the difference in bulk density.

These results indicate a greater variability in the properties of lignocellulosic biomass than has hitherto been reported in the literature, potentially caused by factors including growth conditions, cultivation methods, and post-harvesting handling of the crop.

Based on visual observation, rice husk samples A and B appeared similar. On the other hand, corn cob sample B appeared to have flat, flakey and porous particles while sample A had round particles with a thick outer layer that appeared less porous. The SEM investigation of the biomass particle morphology confirmed a difference in the texture between the rice husks (Figure 4) and corn cobs (Figure 5), and between the two samples of corn cobs. Corn cobs consist of softer, porous particles (Figure 5b), which can aid water penetration, while rice husks have thicker cell walls and fewer openings on particle surfaces, which resist rapid water penetration. The microstructure of corn cob particles implies existence of a capillary network and an associated tendency to absorb water [23].

Consistent with the literature [20,23] (Table 1), the water absorption of the corn cobs was found to be higher than that of the rice husks. For all four biomass samples, the available pore spaces within the biomass residue were oversaturated. The oversaturation of the porosity is observed as swelling (\% volume change in Table 1Table 3), which is typical of most lignocellulosic materials when immersed in fluids such as oil [52] and water.

\subsection{Briquette density and compressive strength}

Columns 7, 9 and 11 of Table 4 show the mean unit densities and compressive strengths of briquettes obtained for each run of the factorial design experiment; the standard deviations for the three replicates of each test are shown in columns 8, 10 and 12 .

Results showed that blending rice husks and corn cobs produced briquettes with a unit density of up to 1.9 times the average bulk density of the loose biomass, and of better strength than briquettes made from the individual materials. The bulk densities of the fuel briquettes in this study were estimated to range from 366 to $570 \mathrm{~kg} / \mathrm{m}^{3}$; the higher value compares well with the $\geq 500$ recommended value for standard solid biofuels under the UK code of good practice [54]. 
For various blends of rice husks and corn cobs, the compressive strengths and relaxed densities obtained were in the range of 25 to $237 \mathrm{kPa}$ and 490 to $712 \mathrm{~kg} / \mathrm{m}^{3}$ respectively. Considering average values from both biomass sources investigated, an unconfined compressive strength of $176 \mathrm{kPa}$ was achieved at a compaction pressure of $31 \mathrm{MPa}$ for a 3:7 blend of rice husks to corn cobs with $10 \%$ binder ( $\operatorname{starch} /$ water $=2: 3$ ). These briquettes were found to be durable with only $4 \%$ mass loss during abrasion and $10 \%$ mass loss during shattering tests. They absorbed 36\% less water than the loose corn cobs. The durability properties of briquettes obtained in this study compare well with those obtained by other researchers [e.g., 17,35,43] for individual agricultural biomass and [e.g., 12,57], for mixed woody biomass, The durability properties fall within the specification of $\leq 12 \%$ moisture content and $<10 \%$ mass loss during shattering and abrasion tests for CEN/TS 14961, the European standard for solid fuel quality [54].

\subsection{Effects of briquetting variables on response variables}

The main (individual) and interaction (two-factor and three-factor) effects of the sample batch, material ratio, binder content and compaction pressure, on the green densities, relaxed densities and compressive strengths of the briquettes in the $2^{4}$ factorial design experiment (Runs 1 to 16), are presented in normal probability plots in Figure 6a to c. The effects that deviate from the straight line in the probability plot are the most significant. The probabilities that the shown effects are attributable to random error, $p$, were determined based on the Fstatistics calculated in the analysis of variance (ANOVA). An effect is generally considered as statistically significant when $p<0.05$ [42]. A normal plot of the residuals from equation 2 showed a straight line, indicating good model fit.

The use of corn cob sample A rather than B had a highly significant positive effect on both green and relaxed densities ( $p=0.0001$ and $p=0.0001$, respectively), but only a small positive effect on compressive strength $(p=0.562)$. Since densification is the primary motivation for briquetting, this effect emphasises the importance of understanding the variability of biomass properties, and possibly the need for consistent pre-treatment of residues before their application as biofuels. The lower rice husk content had a highly significant positive effect on briquette relaxed density and compressive strength $(p=0.0001$ and $p=0.0001$, respectively). The smaller particle size of the corn cobs and their porous nature may have resulted in better compaction. This observation also compares well with findings by other authors [17,35], where briquettes produced from smaller particles sizes 
exhibited less relaxation. There is an increased energy cost associated with biomass grinding, but energy is saved in compaction, as smaller particles are more easily densifiable due to their greater surface area [8] which increases the effect of short range electrostatic and magnetic forces, and causes particles to adhere to each other [56].

The use of the starch/water binder decreased briquette density ( $p=0.003)$, which may be attributable to the low density of the starch/water gel, in comparison with the residues that it replaced, and the possible expansion of briquettes due to heat development during densification. However, the briquettes produced without binder (experimental runs $17^{* *}$ to $\left.20^{* *}\right)$, were crumbly and with negligible compressive strength, and the use of the binder was thus critical to achieve a useful compressive strength, as expected (1.3). It was postulated that the effect of the binder on the briquette responses may be due to the natural presence of binders in most biomass materials, which are activated using moisture or temperature [17]. Therefore, to assess the effect of water separately from that of starch, an ANOVA was conducted for experimental runs 9 to 12 (including starch and water) and $21^{* *}$ to $24 * *$ (including water only), inError! Reference source not found. The results compared well with those for the $2^{4}$ factorial design experiment, and showed that starch had an effect of $16 \mathrm{kPa}(p$ $=0.0001)$ on strength, on top of the effect of water alone. There was also an interaction between sample batch and binder content, which significantly reduced the green density of the briquettes made with corn cob sample B containing the starch binder $(p=0.0040)$. This interaction effect was not apparent for the relaxed density $(p=0.135)$, but had a strong negative effect on the compressive strength $(p=0.0001)$. The use of the higher pressure of $31 \mathrm{MPa}$ yielded a significant positive effect on briquette relaxed density ( $p=0.001$ ), which is consistent with rational expectations and the literature [43].

Table 5 summarises the durability properties of the briquettes with the highest density and compressive strength from Table 4.

Despite the addition of the binder containing water to the blends of rice husks and corn cobs, briquette moisture contents in Table 5 appear within range for good quality briquettes $(\leq$ 12\%) recommended by the European standards for solid fuels CEN/TS 14961 [54]. The briquette moisture contents in this study can also be compared with the range of 9 to $14 \%$ achieved for binderless corn cob briquettes by Kaliyan \& Morey [17]. Curing at $35^{\circ} \mathrm{C}$ significantly reduced the moisture content of briquettes, as a result of increase moisture loss due to elevated temperature. Briquette expansion was mainly due to longitudinal with an 
average of $15 \%$ longitudinal expansion compared with $4 \%$ diametrical. An average reduction in density of briquettes sample A and B was found to be $22 \%$ (Table 5Table 5).

Water absorption of briquettes produced at 3:7 rice husks to corn cobs (repeats of runs $4+, 12$ ) is almost twice that of 1:1 rice husks to corn cobs (repeats of runs $3+, 15$ ). This may be due to the high ratio of porous corn cobs (Figure 5) in the 3:7 blend of rice husks to corn cobs. The over-saturation observed in briquettes can also be related to the swelling nature of lignocellulosic residues that was observed in the raw feed samples (section 3.1).

Shattering and abrasion resistance of briquettes produced from 3:7 blend of rice husks to corn cobs conform with the $<10 \%$ mass loss required by standards for quality assurance of solid biofuels CEN/TS 14961[54]. This compares well with 8 to $12 \%$ mass loss for corn cob briquettes produced at $150 \mathrm{MPa}$ and $85^{\circ} \mathrm{C}$ [17]. The difference in porosity of the briquettes and their individual parent materials was relatively small at 8 to $22 \%$. Whereas relatively low compaction pressures were investigated in this work to reduce energy and equipment costs, preliminary results for the 3:7 blend of the B samples of rice husks and corn cobs, without use of a binder, suggest that a relaxed density of $774 \mathrm{~kg} / \mathrm{m}^{3}$ could be achieved at an increased compaction pressure of $80 \mathrm{MPa}$. The blend ratio may also affect the briquetting process energy consumption; for example, there was a decrease in energy consumption when the blend ratio changed from 30/70 to 50/50 (manuscript in preparation).

\section{CONCLUSIONS}

This study has demonstrated that briquettes of good and consistent quality, which conform to CEN/TS 14961[54], can be produced by blending rice husks and corn cobs.

Statistical analysis of the results showed that the proportion of corn cobs and higher compaction pressure had positive effects on briquette green and relaxed densities, as well as compressive strength. Starch and water binder addition were necessary to achieve measurable unconfined compressive strengths, but significantly reduced the green and relaxed densities of the briquettes. Although the source of the biomass did not affect briquette strength, it had a significant effect on biomass densification.

Further study of the causes and effects of biomass variability is recommended. The negative effect of starch binder on briquette density also indicates the need to explore other sources of binder that do not result in swelling during biomass densification. Further research into the impact of blend ratio on the briquetting process energy consumption is also required. Since 
the maximum storage period for briquettes used in this paper was 7 days, it is important to look into the effect of longer storage periods on briquette quality.

\section{Acknowledgements}

We would like to express our gratitude to the Nigerian Government through the Petroleum Technology Development Fund (PTDF), for sponsoring this research project. Our appreciation also goes to Alvan Blanch Group UK for helping with the size reduction of corn cobs sample B, Dr. Anna Bogush for helping with the SEM analysis, and the staff of the UCL Environmental, Concrete and Structures laboratories.

\section{List of abbreviation}

$\mathrm{M}=$ Material ratio

$\mathrm{B}=$ Binder

$\mathrm{P}=$ Pressure

$\mathrm{S}=$ Sample batch

$\mathrm{ST}=\mathrm{Starch}$

$p=$ Probability

\section{REFERENCES}

[1] P.D. Grover, S.K. Mishra, Biomass Briquetting: Technology and Practice, Food and Agricultural Organisation of the United States, Bangkok Thailand, (1996) 1-10.

[2] A.J. Ragauskas, C.K. Williams, B.H. Davison, G. Britovsek, J. Cairney, C.A. Eckert, W.J. Frederick Jr, J.P. Hallett, D.J. Leak, C.L. Liotta, J.R. Mielenz, R. Murphy, R. Templer, T. Tschaplinski, The Path Forward for Biofuels and Biomaterials, j. science. 311 (2006) 484489.

[3] R.E.H. Sims, W. Mabee, J.N. Saddler, M. Taylor, An overview of second generation biofuel technologies, j. Bioresource Technology 101 (2010) 1570-1580. 
[4] U.R. Fritsche, R.E.H. Sims, A. Monti, Direct and indirect land-use competition issues for energy crops and their sustainable production - an overview, j. Biofuels Bioproducts \& Biorefining4 (2010) 692-704.

[5] E. A. Emerhi Physical and combustion properties of briquettes produced from sawdust of three hardwood species and different organic binders, Advances in Applied Science Research (2011) 1-5.

[6] S. Van Loo, J. Koppejan, Handbook of Biomass Combustion and Co-Firing, Earthscan Publication Ltd, London, UK, (2008).

[7] S.C. Bhattacharya, L. M. Augustus, R. M. Mizanur, A Study on Improved Biomass Briquetting, Energy Program, School of Environment, Resources and Development Asian Institute of Technology(1996) 1-2.

[8] J.S. Tumuluru, C.T. Wright, J.R. Hess, K.L. Kenney, A review of biomass densification systems to develop uniform feedstock commodities for bioenergy application, Idaho National Laboratory, Idaho Falls, ID, USA, j. Biofuels, Bioproducts \& Biorefining, 5 (2011) 683-707.

[9] I. E.Smith, S. D. Probert, R. E. Stokes, R. J. Hansford, The briquetting of wheat straw, j. Agricultural Engineering Resource 22 (1977) 105-111.

[10] K. Demirbas, A. Sahin-Demirbas, Compacting of biomass for energy densification, Energy Sources, and Part A: Recovery, Utilization, and Environmental Effects 31 (2009) 1063-1068.

[11] S. C. Bhattacharya,Biomass energy and densification: A global review with emphasis on developing countries, São Paulo: Centro Nacional de Referência em biomassa (2003) 8-15.

[12] L. Wamukonya, B. Jenkins, Durability and relaxation of sawdust and wheat-straw briquettes as possible fuels for Kenya, j. Biomass and Bioenergy 8 (1995) 175-9.

[13] C. S. Chou, S.H. Lin, C.C. Peng, W.C. Lu , The optimum conditions for preparing solid fuel briquette of rice straw by a piston-mold process using the Taguchi method, Journal of Fuel Processing Technology 90 (2009), 1041-1046. 
[14] RKB, Rice Knowledge Bank, Husk and Straw Properties, International Rice Research Institute (2009), Available at

http://www.knowledgebank.irri.org/rkb/rice-milling/byproducts-and-their-utilization/ricehusk.html Accessed on 23/09/2013 at 16:10.

[15] IGC International Grain Council, Maize, Five-year global supply and demand projections to 2017/18, Available at http://www.igc.int/en/grainsupdate/sd.aspx?crop=Maize Accessed on 30/09/2013 17:25.

[16] A. Demirbas, Relationships between lignin contents and fixed carbon contents of biomass samples, Energy Conversion and Management, volume 44, (2003) 1481-1486.

[17] N. Kaliyan and R.V. Morey, Factors affecting strength and durability of densified biomass products, Biomass Bioenergy (33) (2009) 337-359.

[18] S.V. Vassilev, D. Baxter, L.K. Andersen, C.G. Vassileva, An overview of chemical composition of biomass, j. Fuel 89 (2010) 913-933.

[19] S. Shackley, S. Carter, T. Knowles, E. Middelink, S. Haefele, S. Sohi, A. Cross, S. Haszeldine, Sustainable Gasification - biochar systems. A case study of rice husk gasification in Cambodia, Part I: Context, Chemicals properties, Environmental, Health and Safety issues, Energy Policy, Elsevier Ltd. (2011) 1-10.

[20] A Kr. Thakur, A.K. Gupta, Water absorption characteristics of paddy, brown rice and husk during soaking, j. Food Engineering 75 (2006) 252-257.

[21] Y. Zhang, A.E. Ghaly, B. Li, Physical Properties of Rice Residues as affected by variety and Climatic and Cultivation Conditions in Three Continents, American Journal of Applied Sciences, 9 (2012) 1757-1768.

[22] Y. Zhang, A.E. Ghaly, B. Li, Physical Properties of Corn Residues, American Journal of Biochemistry and Biotechnology 8 (2012) 44-53.

[23] J. Pinto, D. Cruz, A. Paiva, S. Pereira, P. Tavares, L. Fernandes, H. Varum, Characterization of corn cob as a possible raw building material, Construction and Building Materials 34 (2012) 28-33.

[24] J. Vadiveloo, B. Nurfariza , J.G. Fadel, Nutritional improvement of rice husks, Animal Feed Science and Technology 151 (2009) 299-305. 
[25] P.T. Williams, N. Nugranad, Comparison of products from the pyrolysis and catalytic pyrolysis of rice husks, Energy 25 (2000) 493-513.

[26] N.I. Perotti, O.E. Molina, Corn Cob as a Bacterial Substrate for the Production of Forage Protein, Biological Wastes 26 (1988) 125-131.

[27] A.M. Nour, "Rice straw and rice hulls in feeding ruminants in Egypt." Utilisation of Agricultural By-Products as Livestock Feeds in Africa, Food and agricultural organisation (FAO) corporate document repository (1987) 53-61.

[28] J. Steffens, Methods for increasing starch content in plant cobs, EP 2401385 A1 WO2010099134A1), Jan 4, 2012.

[29] S. F. Bazzana, C. E. Camp, B. C. Fox, R. S. Schiffino, K. D. Wing, Ammonia pretreatment of biomass for improved inhibitor profile, WO 2011046818 A2, Apr 21, 2011.

[30] EIA Energy Information Administration United States, International energy statistics, Independent statistics and analysis (2013), Available at http://www.eia.gov/cfapps/ipdbproject/IEDIndex3.cfm?tid=44\&pid=44\&aid=2 Accessed on $03 / 12 / 2013$ at $15: 33$.

[31] HEDON (Household Energy Network), Biomass Densification - Research project of University of Twente, Technology and Development Group (2009), Available at http://www.hedon.info/BP25 Accessed on 26/08/2012 15:54.

[32] A.K. Rajvanshi, Biomass Gasification, Alternative Energy in Agriculture, Energy Sources 2 (1986) 83-104.

[33] A.Demirbaş, Relationship between Initial Moisture Content and the Liquid Yield from Pyrolysis of Sawdust Energy Sources 27 (2005) 823-830.

[34] A.I Bamgboye, S.J Bolufawi, Physical Characteristics of briquettes from guinea corn (sorghum bi-color) residue, the CIGR E-journal, manuscript 1364 (2009) 1-10.

[35] J.T. Oladeji C. C. Enweremadu, The effects of some processing parameters on physical and densification characteristics of corncob briquettes, j. Energy Engineering, 2 (2012)22-27.

[36] M. Satin, Functional Properties of Starches, Agricultural and Food Engineering Technologies Service, Food and Agricultural Organisation (FAO) (1998). 
[37] M. Tako, S. Hizukuri, Gelatinization mechanism of potato starch, Cabohydrate polymers 48 (2002) 397-401.

[38] BS EN 15103: Solid biofuels — Determination of bulk density (2009).

[39] BS EN 14774-2: Solid biofuels - Determination of moisture content - Oven dry method, Part 2: Total moisture — Simplified method (2009).

[40] DD CENT/TS 15149: Draft for Development, British Standards Institution, Solid biofuels - Methods for the determination of particle size distribution - Part 2: Vibrating screen method using sieve apertures of $3.15 \mathrm{~mm}$ and below (2006).

[41] BS EN 772-21: Methods of test for masonry units Part 21: Determination of water absorption of clay and calcium silicate masonry units by cold water absorption (2011).

[42] G.E.P. Box, J.S. Hunter,W.G. Hunter, Statistics for Experimenters, Design, Innovation and Discovery, second edition, John Wiley and Sons, Inc. (2005).

[43] C.O Chin, K.M. Siddiqui, Characteristics of some biomass briquettes prepared under modest die pressures, J. Biomass and Bioenergy 18 (2000) 223-228.

[44] M.I. Al-Widyan, H.F. Al-Jilal, M.M. Abu-Zreig, N.H. Abu-Hamdeh, Physical durability and stability of olive cake briquettes, Canadian Biosystems Engineering 44 (2002) 341-345.

[45] DD CEN/TS 15405: Draft for Development, British Standard Publication, Solid recovered fuels - Determination of density of pellets and briquettes (2010).

[46] ASTM standards, C39-96: Method for compressive strength of cylindrical concrete specimens, Annual book of American Society for Testing and Materials Standard (1998).

[47] DD CEN/TS 15639: Draft for development, British Standards Publication, Solid recovered fuels - Determination of mechanical durability of pellets (2010).

[48] J.A. Lindley, M. Vossoughi, Physical properties of biomass briquettes, Transactions of the ASAE (32) (1989) 361-366.

[49] J.K Raghavan , H.N. Conkle, Physical characteristic measurements for reconstituted coal pellets, proceeding of the Institute for Briquetting and Agglomeration (IBA), 22 (1991) 8596. 
[50] Y. Li, H. Liu , High-pressure densification of wood residues to form an upgraded fuel, j. Biomass and Bioenergy 19 (2000) 177-186.

[51] S. H. Sengar, A. G. Mohod, Y. P. Khandetod, S.S. Patil, A.D. Chendake Performance of Briquetting Machine for Briquette Fuel, Intl. j. Energy Engineering 2(1), (2012) 28-34. Scientific \& Academic Publishing.

[52] S. Ragunathan, H. Ismail, K. Hussin, Mechanical Properties, Water Absorption, And Swelling Behaviour Of Rice Husk Powder Filled Polypropylene/ Recycled Acrylonitrile Butadiene Rubber (Pp/Nbrr/Rhp) Biocomposites Using Silane As A Coupling Agent, BioResources 6 (2011) 3714-3729 .

[53] N. Pampuro, A. Facello and E. Cavallo, Pressure and specific energy requirements for densification of compost derived from swine solid fraction, Spanish journal of agricultural research11(3) (2013) 678-684.

[54] CEN/TS 14961:Technical specifications for pellets according the European Standard, Existing Guidelines on Quality of Fuel Pellets, Pellets for Europe projekt (2004) 14-17.

[55] Yaman, S, Sahan, M, Haykiri-Acma, H, Sesen, K, Kucukbayrak, S: Fuel briquettes from biomass-lignite blends. Fuel processing technology 72 (2001) 1-8.

[56] N. Kaliyan, Densification of Biomass, A dissertation submitted to the faculty of graduate school of the University of Minnesota, ProQuest LLC (2008), Pp: 69-70.

[57] S. J Mitchual., K F.Mensah., N. A. Darkwa., Effect of species, particle size and compacting pressure on relaxed density and compressive strength of fuel briquettes, International J. Energy and Environmental Engineering (2013) 4:30 http://www.journalijeee.com/content/4/1/30.

[58] M. Thomas., T. van Vliet., A.F.B. van der Poel., Physical quality of pelleted animal feed, part 3: Contribution of feedstuff components, Animal Feed Science Technology 70 (1998) 59-78.

[59] C.P. Thoreson, K.E. Webster, M.J. Darr, Technical Note: Durability Analysis of Large Corn Stover Briquettes Agricultural and Biosystems Engineering, Applied Engineering in Agriculture 28 (2012) 9-14. 


\section{LIST OF FIGURES}

Figure 1: Blend of rice husks and corn cobs loaded into the $32 \mathrm{~mm}$ diameter mold

Figure 2: Mold with sample subjected to load in compression machine

Figure 3: Briquettes produced from blends of rice husks and corn cobs

Figure 4: Morphology of rice husks under SEM (Sample B)

Figure 5: Morphology of corn cobs under SEM (Sample B)

Figure 6: Normal probability plots of the effects of sample batch (S), material ratio (M), binder addition (B), compaction pressure (P), and their interactions (MS, BS, PS, MB, MP, PB, MBS, MPS, PBS, MPB, on briquette a) green density, $b$ ) relaxed density and c) compressive strength 

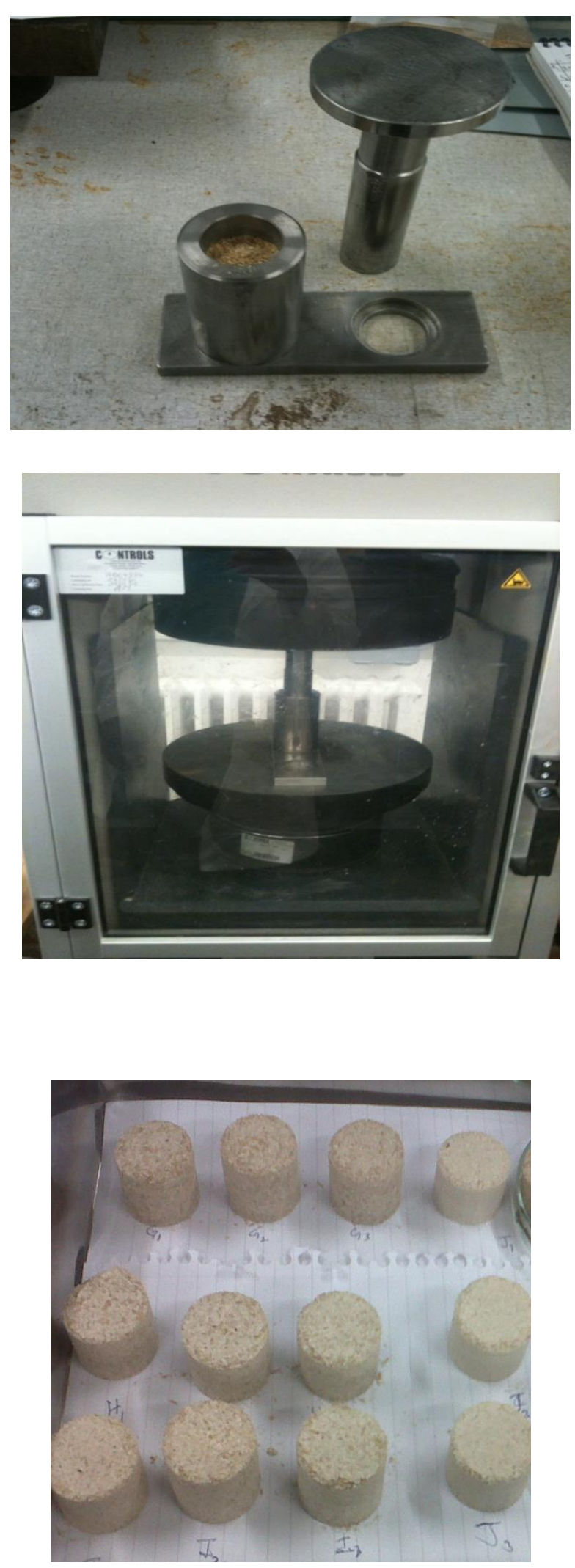

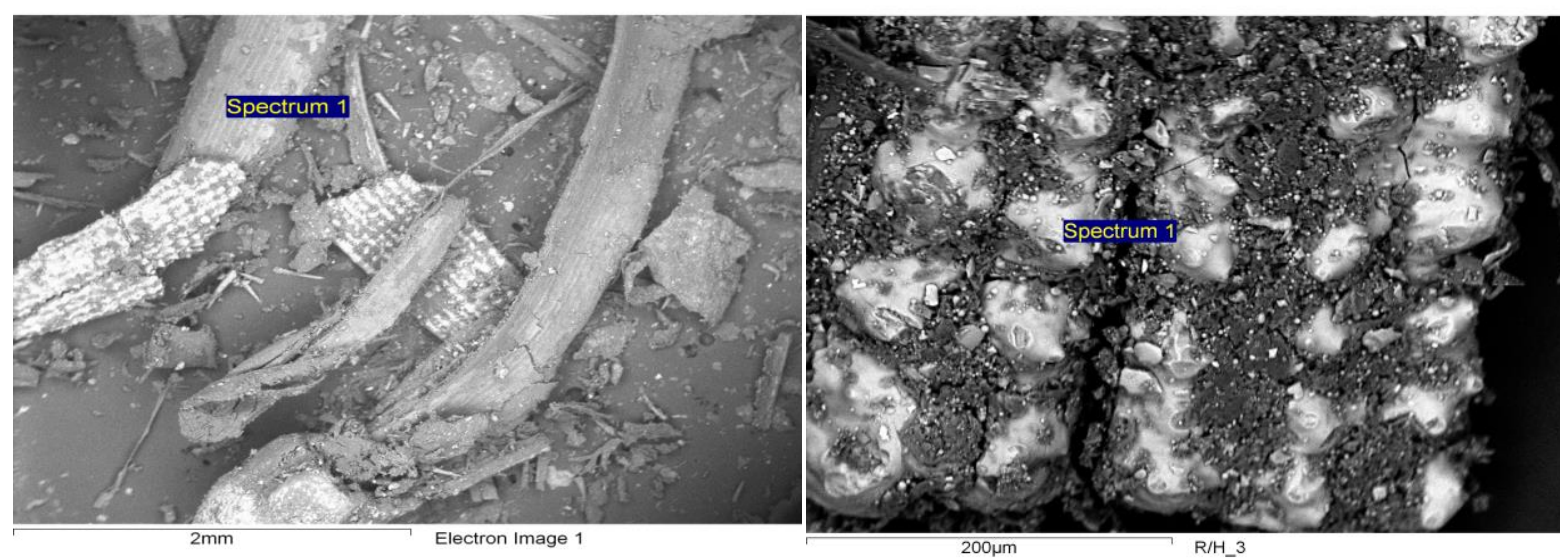

(a)

(b)

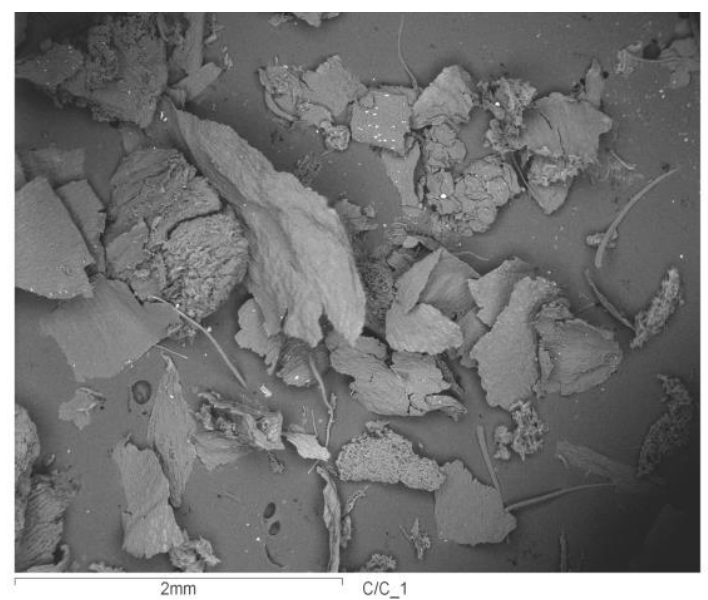

(a)

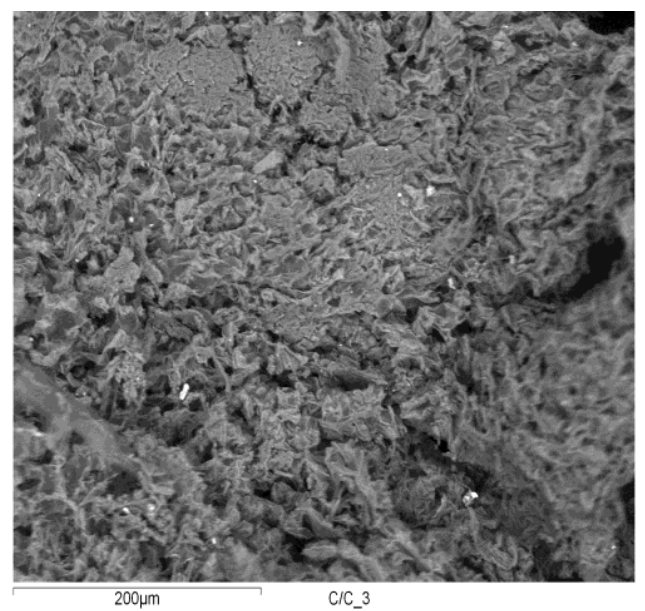

(b) 


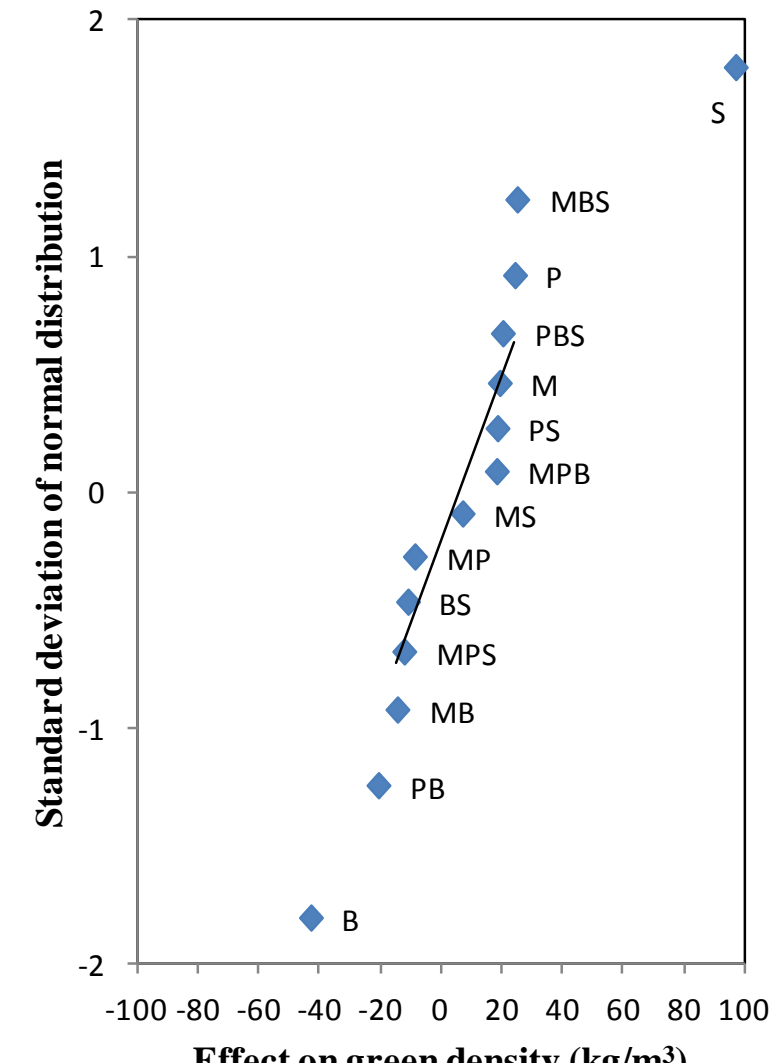

Effect on green density $\left(\mathrm{kg} / \mathrm{m}^{3}\right)$
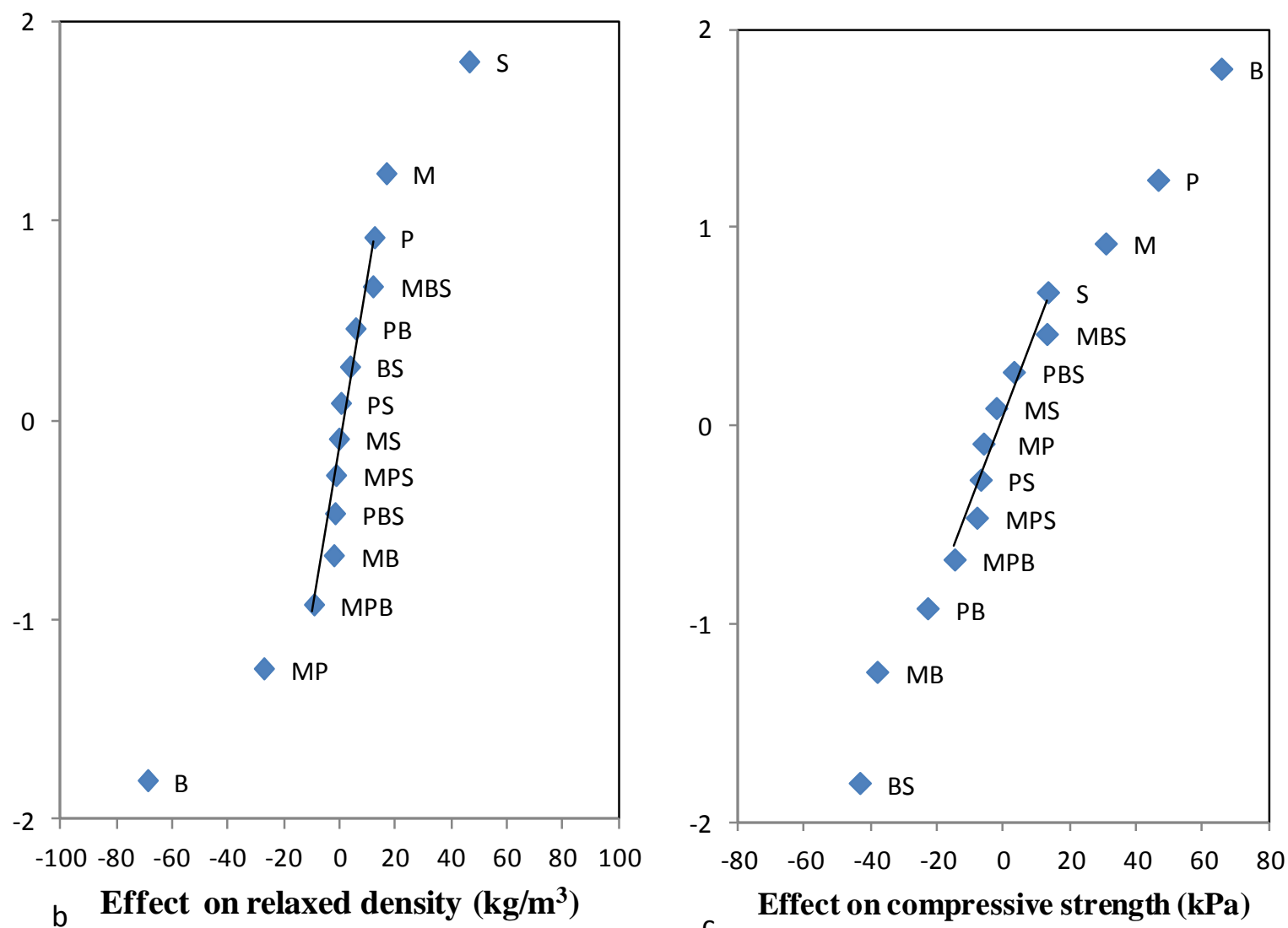
Table 1: Comparison of basic properties of rice husks and corn cobs

\begin{tabular}{|c|c|c|c|c|c|}
\hline \multicolumn{2}{|c|}{ Properties } & \multicolumn{2}{|c|}{ Rice husks } & Corn cobs & Reference \\
\hline \multicolumn{2}{|c|}{ Calorific value (kJ/kg dry mass) } & \multicolumn{2}{|c|}{16000} & 18000 & {$[14,16,18,19]$} \\
\hline \multicolumn{2}{|c|}{ Ash content ( $\%$ dry mass) } & \multicolumn{2}{|c|}{20} & $<2$ & {$[1,14,18,21,22]$} \\
\hline \multicolumn{2}{|c|}{ Moisture content ( $\%$ undried mass) } & \multicolumn{2}{|c|}{$8-12$} & $20-55$ & $14,17,19,21,22]$ \\
\hline \multicolumn{2}{|c|}{$\begin{array}{l}\text { Bulk density (unprocessed) }\left(\mathrm{kg} / \mathrm{m}^{3} \text { dry }\right. \\
\text { mass) }\end{array}$} & \multicolumn{2}{|c|}{$100-150$} & $160-210$ & $14,17,21,22,23]$ \\
\hline \multicolumn{2}{|c|}{$\begin{array}{l}\text { Bulk density (ground to }<0.85 \mathrm{~mm})\left(\mathrm{kg} / \mathrm{m}^{3}\right. \\
\text { dry mass) }\end{array}$} & \multicolumn{2}{|c|}{$331-380$} & 282 & {$[21,22]$} \\
\hline \multicolumn{2}{|c|}{ Porosity (\% dry volume) } & \multicolumn{2}{|c|}{$63-73 *$} & 68 & {$[21,22]$} \\
\hline \multicolumn{2}{|c|}{ Water absorption (\% dried mass) } & \multicolumn{2}{|c|}{105} & $327 * *$ & {$[20,23]$} \\
\hline \multicolumn{2}{|l|}{ Lignin (\% dry mass) } & \multicolumn{2}{|c|}{19.2} & 15.3 & {$[25,29]$} \\
\hline \multicolumn{2}{|c|}{ Protein (\% dry mass) } & \multicolumn{2}{|c|}{1.8} & 2.7 & {$[24,26,27]$} \\
\hline \multicolumn{2}{|c|}{ Starch (\% wt dry mass) } & \multicolumn{2}{|c|}{$<1$} & 1.61 & $[24,28]]$ \\
\hline \multicolumn{6}{|c|}{$*$ range of 4 different types including long and short grain rice } \\
\hline \multicolumn{6}{|c|}{ Table 2: Briquette characterisation methods } \\
\hline Briquette Property & Method Summa & & Stan & ard Test Method & Reference \\
\hline Unit density & Ratio of cylinder mass $t$ & volume & $\mathrm{DDC}$ & $\mathrm{EN} / \mathrm{TS} 15405: 2010$ & [45] \\
\hline Moisture content & Mass lost in drying at 10 & ${ }^{\circ} \mathrm{C} \pm 2$ & & S EN 14774-2 & [38] \\
\hline $\begin{array}{l}\text { Unconfined } \\
\text { compressive strength }\end{array}$ & $\begin{array}{l}\text { Failure loading } \\
\text { axially loaded cyliı }\end{array}$ & & ASTI & [ C39-96 (adapted) & {$[46]$} \\
\hline Abrasion resistance & Mass lost in tumbling & $\mathrm{r} 24 \mathrm{~h}$ & & CEN/TS 15639 & {$[47]$} \\
\hline Shattering resistance & Mass lost in drop fro & $1 \mathrm{~m}$ & & & $\begin{array}{l}\text { adapted from } \\
{[48,49,50,51]}\end{array}$ \\
\hline Water absorption & $\begin{array}{l}\text { Mass gained after soakir } \\
\text { water at room temperatu }\end{array}$ & & & S EN 772-21 & {$[41]$} \\
\hline
\end{tabular}


Table 3: Feed material properties (averages of three measurements)

\begin{tabular}{lcccc}
\hline \multirow{2}{*}{ Raw feed sample } & \multicolumn{2}{c}{ Rice husks } & \multicolumn{2}{c}{ Corn cobs } \\
\cline { 2 - 5 } & Sample A & Sample B & Sample A & Sample B \\
\hline Ash content (\% dry mass) & 19.6 & ND & 4.1 & ND \\
Moisture content (\% undried mass) & 7.0 & 7.0 & 6.9 & 6.8 \\
Specific gravity & 1.50 & 1.50 & 1.47 & 1.46 \\
Bulk density (dried mass, $\mathrm{kg} / \mathrm{m}^{3}$ ) & 363 & 354 & 395 & 278 \\
Porosity (\% of uncompacted volume) & 75 & 76 & 73 & 81 \\
Water absorption (\% dried mass) & 112 & 160 & 168 & 289 \\
$\quad$ (\% saturation of porosity) & 48 & 109 & 130 & 251 \\
$\quad$ (\% volume change) & 29.4 & ND & 40 & ND \\
Particle size (mm) & $<2$ & $<2$ & $<1.6$ & $<1.6$ \\
\hline
\end{tabular}

$\mathrm{ND}=$ Not determined 
Table 4: Briquette density and strength measured in a factorial design with sample batch, material ratio, binder content and compaction pressure

\begin{tabular}{|c|c|c|c|c|c|c|c|c|c|c|c|}
\hline \multirow{4}{*}{ Run } & \multicolumn{5}{|c|}{ VARIABLES } & \multicolumn{6}{|c|}{ RESPONSES* } \\
\hline & \multirow{3}{*}{$\begin{array}{c}\text { Sample } \\
\text { batch }(S)\end{array}$} & \multirow{3}{*}{$\begin{array}{c}\text { Material ratio }(\mathrm{M}) \\
(\% \text { mass of } \\
\text { rice husks in rice } \\
\text { husk/corn cob } \\
\text { blend })\end{array}$} & \multicolumn{2}{|c|}{ Binder (B) } & \multirow{3}{*}{$\begin{array}{c}\text { Pressure (P) } \\
\text { (MPa) }\end{array}$} & \multirow{2}{*}{\multicolumn{2}{|c|}{$\begin{array}{c}\text { Unit Green } \\
\text { Density }\left(\mathrm{kg} / \mathrm{m}^{3}\right)\end{array}$}} & \multirow{2}{*}{\multicolumn{2}{|c|}{$\begin{array}{c}\text { Unit Relaxed } \\
\text { Density }\left(\mathbf{k g} / \mathbf{m}^{3}\right)\end{array}$}} & \multirow{2}{*}{\multicolumn{2}{|c|}{$\begin{array}{c}\text { Compressive } \\
\text { Strength (kPa) }\end{array}$}} \\
\hline & & & \multirow{2}{*}{$\begin{array}{c}\text { (\% mass of } \\
\text { starch in rice } \\
\text { husk/corn } \\
\text { cob blend) }\end{array}$} & \multirow{2}{*}{$\begin{array}{l}\text { (\% mass of } \\
\text { added water in } \\
\text { rice husk/corn } \\
\text { cob blend) }\end{array}$} & & & & & & & \\
\hline & & & & & & mean & SD & mean & SD & mean & SD \\
\hline 1 & $\mathrm{~A}$ & 50 & 4 & 6 & 19 & 815 & 15 & 616 & 18 & 70 & 4 \\
\hline 2 & A & 30 & 4 & 6 & 19 & 867 & 14 & 671 & 41 & 152 & 7 \\
\hline 3 & A & 50 & 4 & 6 & 31 & 896 & 17 & 673 & 19 & 158 & 1 \\
\hline $3+$ & $\mathrm{A}$ & 50 & 4 & 6 & 31 & 830 & 19 & 664 & 8 & 148 & 1 \\
\hline 4 & A & 30 & 4 & 6 & 31 & 874 & 17 & 631 & 11 & 183 & 7 \\
\hline $4+$ & $\mathrm{A}$ & 30 & 4 & 6 & 31 & 870 & 11 & 660 & 10 & 179 & 3 \\
\hline 5 & A & 50 & 6 & 11 & 19 & 767 & 40 & 556 & 13 & 151 & 19 \\
\hline 6 & $\mathrm{~A}$ & 30 & 6 & 11 & 19 & 808 & 26 & 592 & 9 & 155 & 4 \\
\hline 7 & A & 50 & 6 & 11 & 31 & 815 & 36 & 583 & 16 & 171 & 9 \\
\hline 8 & A & 30 & 6 & 11 & 31 & 846 & 25 & 596 & 22 & 175 & 14 \\
\hline 9 & B & 50 & 4 & 6 & 19 & 698 & 23 & 593 & 22 & 25 & 7 \\
\hline 10 & B & 30 & 4 & 6 & 19 & 766 & 10 & 612 & 33 & 64 & 9 \\
\hline 11 & $\mathrm{~B}$ & 50 & 4 & 6 & 31 & 761 & 21 & 586 & 39 & 59 & 8 \\
\hline 12 & $\mathrm{~B}$ & 30 & 4 & 6 & 31 & 795 & 9 & 629 & 15 & 189 & 14 \\
\hline 13 & B & 50 & 6 & 11 & 19 & 767 & 4 & 490 & 24 & 168 & 11 \\
\hline 14 & B & 30 & 6 & 11 & 19 & 715 & 20 & 556 & 29 & 191 & 6 \\
\hline 15 & $\mathrm{~B}$ & 50 & 6 & 11 & 31 & 707 & 27 & 572 & 10 & 237 & 21 \\
\hline 16 & $\mathrm{~B}$ & 30 & 6 & 11 & 31 & 703 & 15 & 512 & 5 & 177 & 16 \\
\hline $17 * *$ & $\mathrm{~B}$ & 50 & 0 & 0 & 19 & 316 & 0 & 316 & 0 & 0 & 0 \\
\hline $18 * *$ & B & 30 & 0 & 0 & 19 & 607 & 28 & 301 & 0 & 0 & 0 \\
\hline
\end{tabular}


Table 4: Briquette density and strength measured in a factorial design with sample batch, material ratio, binder content and compaction pressure

\begin{tabular}{|c|c|c|c|c|c|c|c|c|c|c|c|}
\hline \multirow{4}{*}{ Run } & \multicolumn{5}{|c|}{ VARIABLES } & \multicolumn{6}{|c|}{ RESPONSES* } \\
\hline & \multirow{3}{*}{$\begin{array}{c}\text { Sample } \\
\operatorname{batch}(S)\end{array}$} & \multirow{3}{*}{$\begin{array}{c}\text { Material ratio }(\mathrm{M}) \\
(\% \text { mass of } \\
\text { rice husks in rice } \\
\text { husk/corn cob } \\
\text { blend })\end{array}$} & \multicolumn{2}{|c|}{ Binder (B) } & \multirow{3}{*}{$\begin{array}{l}\text { Pressure (P) } \\
\text { (MPa) }\end{array}$} & \multirow{2}{*}{\multicolumn{2}{|c|}{$\begin{array}{c}\text { Unit Green } \\
\text { Density }\left(\mathrm{kg} / \mathrm{m}^{3}\right)\end{array}$}} & \multirow{2}{*}{\multicolumn{2}{|c|}{$\begin{array}{c}\text { Unit Relaxed } \\
\text { Density }\left(\mathrm{kg} / \mathrm{m}^{3}\right)\end{array}$}} & \multirow{2}{*}{\multicolumn{2}{|c|}{$\begin{array}{c}\text { Compressive } \\
\text { Strength (kPa) }\end{array}$}} \\
\hline & & & \multirow{2}{*}{$\begin{array}{c}\% \text { mass of } \\
\text { starch in rice } \\
\text { husk/corn } \\
\text { cob blend })\end{array}$} & \multirow{2}{*}{$\begin{array}{c}\text { (\% mass of } \\
\text { added water in } \\
\text { rice husk/corn } \\
\text { cob blend) }\end{array}$} & & & & & & & \\
\hline & & & & & & mean & SD & mean & SD & mean & SD \\
\hline $19 * *$ & $\mathrm{~B}$ & 50 & 0 & 0 & 31 & 659 & 46 & 316 & 0 & 0 & 0 \\
\hline $20 * *$ & B & 30 & 0 & 0 & 31 & 615 & 37 & 549 & 13 & 0 & 0 \\
\hline $21 * *$ & B & 50 & 0 & 6 & 19 & 752 & 10 & 623 & 26 & 59 & 4 \\
\hline $22 * *$ & $\mathrm{~B}$ & 30 & 0 & 6 & 19 & 791 & 36 & 695 & 14 & 98 & 4 \\
\hline $23 * *$ & $\mathrm{~B}$ & 50 & 0 & 6 & 31 & 777 & 16 & 642 & 11 & 48 & 4 \\
\hline $24 * *$ & $\mathrm{~B}$ & 30 & 0 & 6 & 31 & 812 & 27 & 712 & 11 & 70 & 4 \\
\hline
\end{tabular}

* Average of three responses; SD is standard deviation

** Experimental runs for effect of water only on briquette responses 
Table 5: Durability properties of briquettes at different curing conditions

\begin{tabular}{|c|c|c|c|c|c|}
\hline Briquette properties & $\begin{array}{c}\text { Run } \\
\text { from Table } 4\end{array}$ & $\begin{array}{c}\text { Curing } \\
\text { temperature } \\
\left({ }^{\circ} \mathrm{C} \pm 2^{\circ} \mathrm{C}\right)\end{array}$ & $\begin{array}{l}\text { Curing } \\
\text { time } \\
\text { (d) }\end{array}$ & $\begin{array}{c}\text { Response } \\
\text { (sample } \\
\text { A) } \\
\end{array}$ & $\begin{array}{c}\text { Response } \\
\text { (sample } \\
\text { B) }\end{array}$ \\
\hline \multirow{11}{*}{$\begin{array}{l}\text { Unit relaxed density } \\
\left(\mathrm{kg} / \mathrm{m}^{3}\right)\end{array}$} & $3+$ & 23 & 1 & 664 & ND \\
\hline & 15 & 23 & 1 & ND & 572 \\
\hline & 3 (repeat) & 23 & 7 & 645 & ND \\
\hline & 15 (repeat) & 23 & 7 & ND & 616 \\
\hline & 15 (repeat) & 35 & 1 & ND & 586 \\
\hline & 3 (repeat) & 35 & 1 & 586 & ND \\
\hline & 3 (repeat) & 35 & 7 & 531 & ND \\
\hline & $4+, 12$ & 23 & 1 & 660 & 629 \\
\hline & 4, 12 (repeat) & 23 & 7 & 644 & 669 \\
\hline & 4 (repeat) & 35 & 1 & 660 & ND \\
\hline & 4 (repeat) & 35 & 7 & 600 & ND \\
\hline \multirow{11}{*}{$\begin{array}{l}\text { Reduction in unit density } \\
\text { (after storage) (\% of } \\
\text { green density) }\end{array}$} & $3+$ & 23 & 1 & 20 & ND \\
\hline & 15 & 23 & 1 & ND & 19 \\
\hline & 3 (repeat) & 23 & 7 & 28 & ND \\
\hline & 15 (repeat) & 23 & 7 & ND & 13 \\
\hline & 15 (repeat) & 35 & 1 & ND & 17 \\
\hline & 3 (repeat) & 35 & 1 & 35 & ND \\
\hline & 3 (repeat) & 35 & 7 & 40 & ND \\
\hline & $4+, 12$ & 23 & 1 & 24 & 21 \\
\hline & 4, 12 (repeat) & 23 & 7 & 26 & 16 \\
\hline & 4 (repeat) & 35 & 1 & 24 & ND \\
\hline & 4 (repeat) & 35 & 7 & 30 & ND \\
\hline \multirow{11}{*}{$\begin{array}{l}\text { Densification } \\
\text { (proportion of average } \\
\text { loose biomass density } \\
\text { of } 348 \mathrm{~kg} / \mathrm{m}^{3} \text { ) }\end{array}$} & $3+$ & 23 & 1 & 1.9 & ND \\
\hline & 15 & 23 & 1 & ND & 1.6 \\
\hline & 3 (repeat) & 23 & 7 & 1.9 & ND \\
\hline & 15 (repeat) & 23 & 7 & ND & 1.8 \\
\hline & 15 (repeat) & 35 & 1 & ND & 1.7 \\
\hline & 3 (repeat) & 35 & 1 & 1.7 & ND \\
\hline & 3 (repeat) & 35 & 7 & 1.5 & ND \\
\hline & $4+, 12$ & 23 & 1 & 1.9 & 1.8 \\
\hline & 4, 12 (repeat) & 23 & 7 & 1.9 & 1.9 \\
\hline & 4 (repeat) & 35 & 1 & 1.9 & ND \\
\hline & 4 (repeat) & 35 & 7 & 1.7 & ND \\
\hline \multirow{4}{*}{$\begin{array}{l}\text { Moisture content } \\
\text { (\% undried mass) }\end{array}$} & $3+$ & 23 & 1 & 9 & ND \\
\hline & 15 & 23 & 1 & ND & 12 \\
\hline & 15 & 35 & 1 & ND & 6 \\
\hline & $4+, 12$ & 23 & 1 & 10 & 10 \\
\hline \multirow{3}{*}{$\begin{array}{l}\text { Porosity } \\
\text { (\% volume) }\end{array}$} & $3+$ & 23 & 1 & 59 & ND \\
\hline & 15 & 23 & 1 & ND & 65 \\
\hline & $4+, 12$ & 23 & 1 & 60 & 60 \\
\hline \multirow{3}{*}{$\begin{array}{l}\text { Water absorption } \\
\text { (\% dried mass) }\end{array}$} & $3+$ & 23 & 1 & 70 & ND \\
\hline & 15 & 23 & 1 & ND & 66 \\
\hline & $4+, 12$ & 23 & 1 & 142 & 151 \\
\hline \multirow[t]{3}{*}{ (\% saturation of porosity) } & $3+$ & 23 & 1 & 118 & ND \\
\hline & 15 & 23 & 1 & ND & 100 \\
\hline & $4+, 12$ & 23 & 1 & 237 & 245 \\
\hline \multirow{3}{*}{$\begin{array}{l}\text { Compressive strength } \\
(\mathrm{kPa})\end{array}$} & $3+$ & 23 & 1 & 148 & ND \\
\hline & 15 & 23 & 1 & ND & 237 \\
\hline & 3 (repeat) & 23 & 7 & 98 & ND \\
\hline
\end{tabular}




\begin{tabular}{|c|c|c|c|c|c|}
\hline Briquette properties & $\begin{array}{c}\text { Run } \\
\text { from Table } 4\end{array}$ & $\begin{array}{c}\text { Curing } \\
\text { temperature } \\
\left({ }^{\circ} \mathrm{C} \pm 2^{\circ} \mathrm{C}\right)\end{array}$ & $\begin{array}{l}\text { Curing } \\
\text { time } \\
\text { (d) }\end{array}$ & $\begin{array}{c}\text { Response } \\
\text { (sample } \\
\text { A) }\end{array}$ & $\begin{array}{c}\text { Response } \\
\text { (sample } \\
\text { B) }\end{array}$ \\
\hline & 15 (repeat) & 23 & 7 & ND & 180 \\
\hline & 3 (repeat) & 35 & 1 & 73 & ND \\
\hline & 3 (repeat) & 35 & 7 & 60 & ND \\
\hline & $4+, 12$ & 23 & 1 & 179 & 189 \\
\hline & 4, 12 (repeat) & 23 & 7 & 167 & 167 \\
\hline & 4 (repeat) & 35 & 1 & 135 & ND \\
\hline & 4 (repeat) & 35 & 7 & 130 & ND \\
\hline \multirow{3}{*}{$\begin{array}{l}\text { Shattering resistance } \\
\text { (\% undried mass loss) }\end{array}$} & $3+$ & 23 & 1 & 14 & ND \\
\hline & 15 & 23 & 1 & ND & 4 \\
\hline & $4+, 12$ & 23 & 1 & 9 & 11 \\
\hline \multirow{3}{*}{$\begin{array}{l}\text { Abrasion resistance } \\
\text { (\% undried mass loss) }\end{array}$} & $3+$ & 23 & 1 & 20 & ND \\
\hline & 15 & 23 & 1 & ND & 3 \\
\hline & $4+, 12$ & 23 & 1 & 3 & 4 \\
\hline
\end{tabular}

